\title{
High Power Three Phase Motor Control Using PLC Siemens S 7-300
}

\author{
Mohamed Hassan Ali Mohamed ${ }^{1}$, Dalia Mahmoud ${ }^{2}$ \\ ${ }^{1}$ Alneelain University, College of Graduates Studies, MSC in Program Control System, Khartoum Sudan \\ ${ }^{2}$ Assistan professor, Control Engineering Department, Alneelain University, Khartoum, Sudan
}

\begin{abstract}
The objective of this paper is to study and learn how to connect the three phase motor Star / Delta and how to apply the protection of the motor at the start of the high current starter. The three phase motor is conversion to the delta connection by programmable logical control. After converted to the delta connection of the three phases motor continues with the same speed and power. These keep the motor from damage and ensure its longer operational life.
\end{abstract}

Keywords: Three Phase Motor, the Programmable Logic Controller, Star/Delta Connection, Overload

\section{Introduction}

Electric Motor it's a device that converts the electrical energy into mechanical energy. Mechanical energy has multiple uses and has different formats such as fans, pump etc. Electric motors are used at home and in industry. It is estimated that electric motor bear about $70 \%$ of the electrical loads [1].

Electrical systems can be generated the direct current by the dynamo. Three phase motors begin to spin on its own and do not need capacitive such as what is happening in the singlephase motors [2].

There are many types of electrical motors, you can choose the motor according to the application on, like two-speed motors, or brake motors, or three-phase motors, or synchronous motors, or single phase and asynchronous motors [3].

More types of motors used in industrial are the three-phase induction motors. Because it works on the constant speed of no load to full load. Also, can be manufactured according to industrial requirements, a simple, low cost and easy conservation [4].

\section{The Programmable Logic Controller}

Is a special type of controllers used memory for programming and to save your commands and instructions to execute specific tasks based on the timing and sequencing and counting all of that in order to control machines [5].

The PLCs based the input devices such as sensors and switches etc. Input signals are processed and given a signal to output. The output signal is active the motor Contactors devices or lamp or valve etc.

- Designed to operate in harsh industrial environments that have high temperatures and high humidity and has a high ability to withstand vibrations.

- The communicating with the processing of the input and output actually inside the controller.

- It programmed with ease one of the programming languages allocated to them [5].

\section{Basic Components of PLCs Systems}

There are different forms of The Programmable Logic Controller PLCs units in size, cost and kinds but similar in the input and output, processor units, communications, memories and power supply [6].

\section{The Processor}

The processor (or the CPU), is determined according to the memory program being implemented [7].

\section{Problem Statement}

It is known that when you started the motors rotation pulls very high current in some cases up to 6 Fold from normal current, for example, $5 \mathrm{KW}$ his current normal $=10 \mathrm{~A}$, but when you start racing currently $=\sim(70$ to $100 \mathrm{~A})$. If the motor power of $55 \mathrm{KW}$ his current normal $=110 \mathrm{~A}$, but open current could be up to 600 amps and more this current affects to:

- Motor coils, with repeated starts collapsing isolate Motor coils and burns the entire motor.

- Add to that the high starting current causes damage Contactors feeder points of contact of the motor

- It is often found that the points of contact have stuck with each other because of a spark from start causing damage to stream contactor.

\section{Objectives}

The primary objectives of this paper are:

- To study and understand the three phase motor.

- To study programmable logic controller concept.

Design circuit to control the three-phase motor so that protected the motor from the high current when it begins to operate. Using programmable logic controllers (PLC) and will use one modeling and simulation programs for (PLC) product company Siemens kind S7-300.This is done by simulation program follow to Siemens called Sematic Manager Step7 Version 5.5. 


\section{International Journal of Science and Research (IJSR) \\ ISSN (Online): 2319-7064}

Index Copernicus Value (2013): 6.14 | Impact Factor (2014): 5.611

\subsection{Methodology}

The programmable logic controller will be used to control the three phase motor. The flowchart is shown in Figure 1 gives the details of the process.

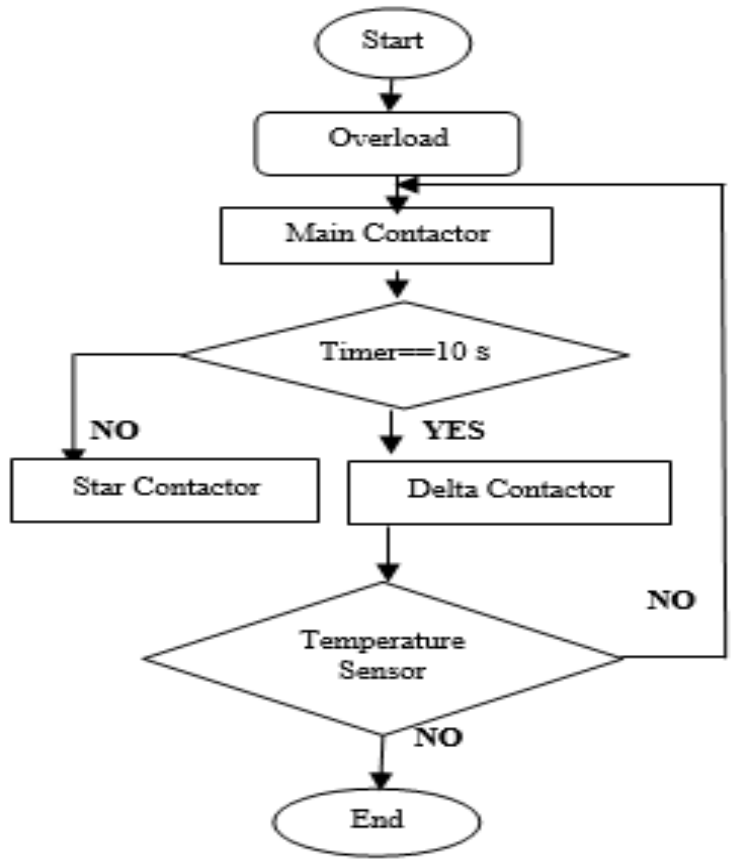

Figure 1: The Flowchart of the High Power Three Phase Motor

The main Contactor will be turned on, after that, the star contactor and timer will be turned on automatically. When the timer signal read 1 , then delta contactor will be turned on. If the temperature sensor [PTC thermistors as limit temperature sensor] reads a value higher than $160{ }^{\circ} \mathrm{C}$, the motor will be shut down. Motor works again when the temperature drops to $90{ }^{\circ} \mathrm{C}$.

\section{Description Process of the System}

Programmable logic controller simulation has been used to control three phase motor connection star/delta. Figure 2. describes a power circuit of three-phase motor, which contains three Contactors, Contactor (C1) represents main Contactor works when to pressing the start Push button, Contactor (C2) which starts work with Contactor principal at the same moment that represents the star connection, Contactor (C3) represents a Delta connection and the motor running after a certain period of run contactor main.

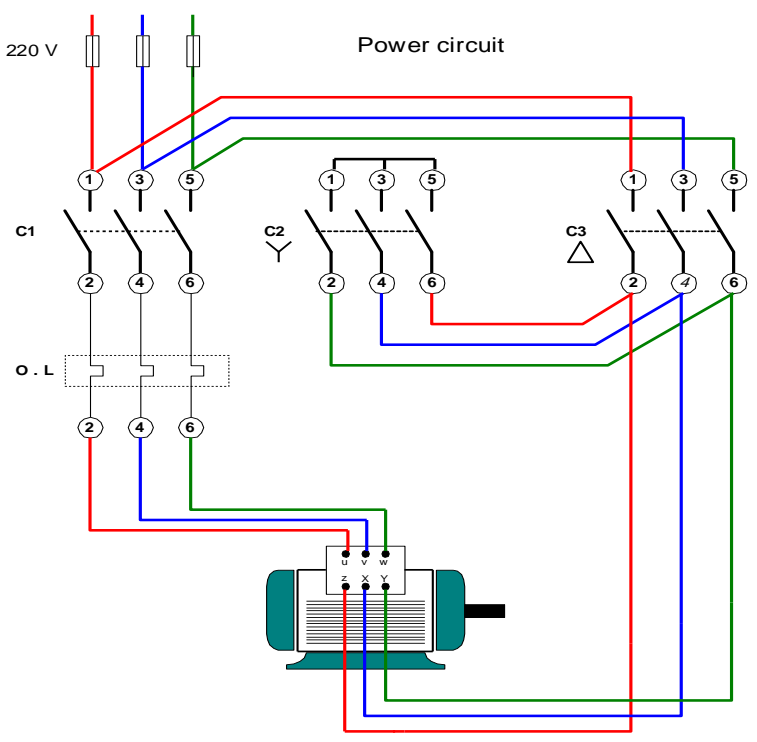

Figure 2: The Power Circuit of Three Phase Motor Star/Delta Connection

Software Component

- Normally open contact (start or stop Push button and sensors)

- Normally close contact (start or stop Push button and sensors)

- Output coil( motor)

- Timers(on delay)

Three phase motor Star/Delta connection in Simens S7-300 simulation programming consists a number of elements. Table 1 shows that.

The control circuit of three phase motor Star/Delta connection in Siemens S7-300 simulation programming consists of ladder diagram The following Figure 3. shown that.

Table 1: Shown a number of elements in Simens S7-300 simulation.

\begin{tabular}{|c|c|}
\hline Symbol & Mean \\
\hline $\mathrm{i} 0.0$ & Start \\
\hline $\mathrm{i} 0.1$ & Stop \\
\hline $\mathrm{i} 0.2$ & Overload \\
\hline $\mathrm{i} 0.3$ & Temperature sensor \\
\hline $\mathrm{T} 1$ & On delay timer \\
\hline $\mathrm{Q} 4.0$ & Main Contactor \\
\hline $\mathrm{Q} 4.1$ & Star Contactor \\
\hline $\mathrm{Q} 4.2$ & Delta Contactor \\
\hline $\mathrm{Q} 4.3$ & Marc \\
\hline
\end{tabular}




\section{International Journal of Science and Research (IJSR) \\ ISSN (Online): 2319-7064}

Index Copernicus Value (2013): 6.14 | Impact Factor (2014): 5.611

Network 1:

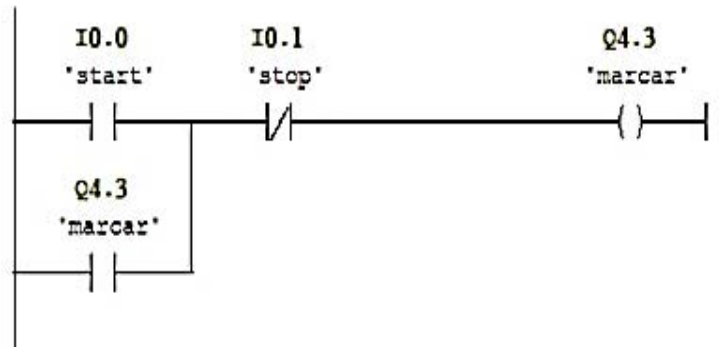

Network 2:

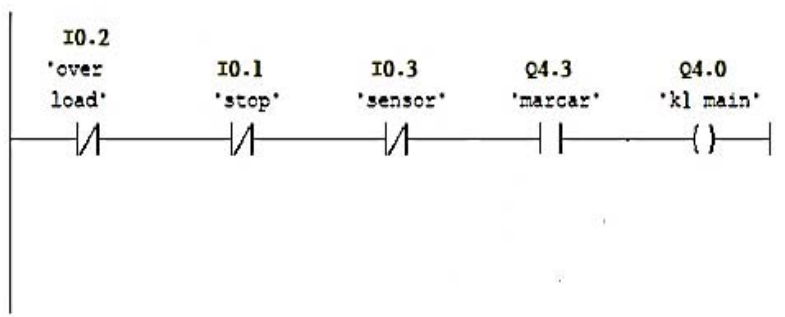

Network 3:

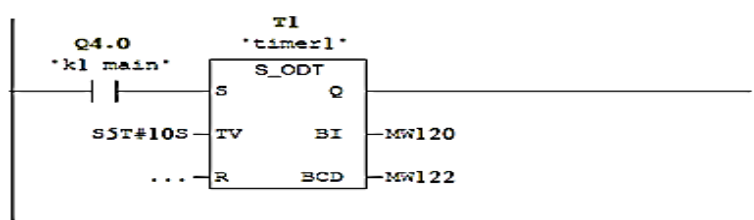

Network 4:

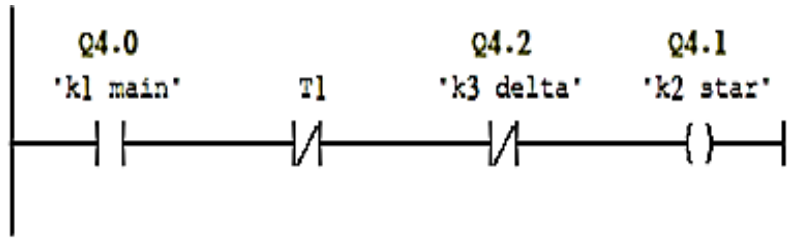

Network 5:

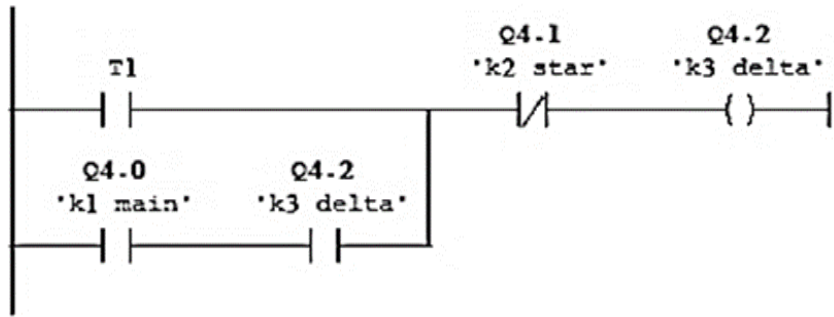

Figure 3: Control Circuit of Three Phase Motor Star/Delta Connection

In network 1contact normally open (start to Push button I0.0) connected parallel with contact normally open (Marc Q4.3) and connected series with contact normally closed (stop Push button I0.1). The coil (Marc Q4.3) represents the output of the network 1. The Marc is used to clarify that the system works normally.

In network 2 the contact normally closed (overload I0.2) connected series with contact normally closed (stop Push button I0.1), contact normally closed (sensor I0.3) and (Marc Q4.3). The contact normally open (main Contactor Q4.0) connect parallel with contact normally open (Marc Q4.0) The output coil (main Contactor Q4.0 ) represents the output of the network 2.

In network 3 the contact normally open ( main contactor Q4.0) represents the input of the timer on delay (T1). The timer on delay consists of:

S: set of the timer

$\mathrm{R}$ : reset of the timer

TV: time value (s5t\#10s)

Q: output of the timer

In the network the contact normally open (main Contactor Q4.0) connected series with contact normally closed (timer T1) and contact normally closed (delta Contactor). The output coil (star Contactor Q4.1) represents the output of the network 4.

In network 5 the contact normally open (main Contactor Q4.0) connected series with contact normally open ( delta Contactor Q4.2) and both connected parallel with contact normally open (timer on delay T1). The contact normally open (timer on delay T1) connect series with contact normally closed (star Contactor Q4.1). The output coil (delta contactor Q4.2 ) represents the output of the network 5.

\section{Simulation Diagram}

Programmable logic controller simulation Step7 Version 5.5 will be used control the three-phase motor so that it converts of Star connection to Delta connection automatic in Figure 4.

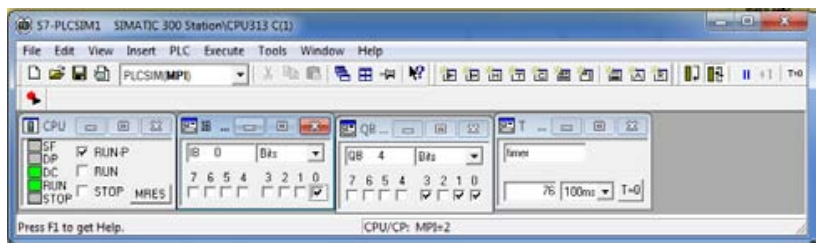

Figure 4: Simulation Diagram Main and Star Connection of Motor

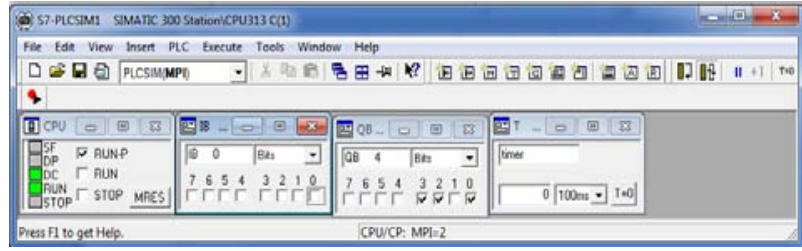

Figure 5: Simulation Diagram Delta Connection of Motor

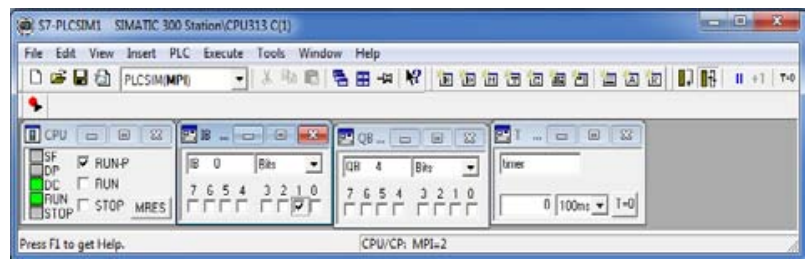

Figure 6: Simulation Diagram Stop Circuit of Motor 


\section{International Journal of Science and Research (IJSR) \\ ISSN (Online): 2319-7064 \\ Index Copernicus Value (2013): 6.14 | Impact Factor (2014): 5.611}

\subsection{Simulation Results}

Siemens S7-300 was used to programmed the PLC Initially When the operator press start it is press works the main and star Contactors at same time, continue star Contactor at work until the capacity reaches $80 \%$ of the total power of the motor and the amount of time in which up to this power ratio by nearly 10 seconds shown in table 2 .

Table 2: The Operation of the Main and Star Contactors of the Motor.

\begin{tabular}{|c|c|c|c|c|c|}
\hline & Address & Symbol & $\begin{array}{l}\text { Display } \\
\text { format }\end{array}$ & $\begin{array}{l}\text { Status } \\
\text { value }\end{array}$ & $\begin{array}{r}\text { Modify } \\
\text { value }\end{array}$ \\
\hline 1 & MW120 & & DEC & 89 & \\
\hline 2 & MW122 & & DEC & 4233 & \\
\hline 3 & I 0.0 & Start pub & $\mathrm{BOOL}$ & II tre & true \\
\hline 4 & I 0.1 & Stop pub & $\mathrm{BOOL}$ & tolso & \\
\hline 5 & I 0.2 & Overload & $\mathrm{BOOL}$ & talse & \\
\hline 6 & I 0.3 & Sensor & $\mathrm{BOOL}$ & talso & \\
\hline 7 & Q 4.0 & K1 main contactor & $\mathrm{BOOL}$ & II true & \\
\hline 8 & Q 4.1 & K2 star contactor & $\mathrm{BOOL}$ & C true & \\
\hline 9 & Q 4.2 & K3 delta contactor & $\mathrm{BOOL}$ & Tolso & \\
\hline 10 & Q 4.3 & Marcar & $\mathrm{BOOL}$ & D tue & \\
\hline
\end{tabular}

When the start Push button is release the circuit continues in their work because it consist of the latch. That is shown in Table 3.

Table 3: Latching Operation

\begin{tabular}{|c|c|c|c|c|c|}
\hline & Address & Symbol & $\begin{array}{l}\text { Display } \\
\text { format }\end{array}$ & $\begin{array}{c}\text { Status } \\
\text { value }\end{array}$ & $\begin{array}{l}\text { Modify } \\
\text { value }\end{array}$ \\
\hline 1 & MW120 & & $\mathrm{DEC}$ & 71 & \\
\hline 2 & MW122 & & DEC & 4209 & \\
\hline 3 & I 0.0 & Start pub & $\mathrm{BOOL}$ & folse & true \\
\hline 4 & I 0.1 & Stop pub & $\mathrm{BOOL}$ & folse & \\
\hline 5 & I 0.2 & overload & $\mathrm{BOOL}$ & tolse & \\
\hline 6 & I 0.3 & sensor & $\mathrm{BOOL}$ & tolse & \\
\hline 7 & Q 4.0 & $\mathrm{K} 1$ main contactor & $\mathrm{BOOL}$ & II true & \\
\hline 8 & Q 4.1 & K2 star contactor & $\mathrm{BOOL}$ & II true & \\
\hline 9 & Q 4.2 & K3 delta contactor & BOOL & folse & \\
\hline 10 & Q 4.3 & marcar & $\mathrm{BOOL}$ & Il true & \\
\hline
\end{tabular}

After the arrival of the power of the motor to $80 \%$ of the total power, convert from star connection to Delta connection automatically. Shown in table 4.

Table 4: Delta Connection of the Motor.

\begin{tabular}{|c|c|c|c|c|c|}
\hline & Address & Symbol & $\begin{array}{l}\text { Display } \\
\text { format }\end{array}$ & $\begin{array}{c}\text { Status } \\
\text { value }\end{array}$ & $\begin{array}{r}\text { Modify } \\
\text { value }\end{array}$ \\
\hline 1 & MW120 & & DEC & 0 & \\
\hline 2 & MW122 & & DEC & 4096 & \\
\hline 3 & I 0.0 & Start pub & $\mathrm{BOOL}$ & falso & true \\
\hline 4 & I 0.1 & Stop pub & $\mathrm{BOOL}$ & folso & \\
\hline 5 & I 0.2 & overload & $\mathrm{BOOL}$ & tolso & \\
\hline 6 & I 0.3 & sensor & $\mathrm{BOOL}$ & false & \\
\hline 7 & Q 4.0 & $\mathrm{K} 1$ main contactor & $\mathrm{BOOL}$ & II true & \\
\hline 8 & Q 4.1 & K2 star contactor & $\mathrm{BOOL}$ & folso & \\
\hline 9 & Q 4.2 & $\mathrm{K} 3$ delta contactor & $\mathrm{BOOL}$ & DI true & \\
\hline 10 & Q 4.3 & marcar & $\mathrm{BOOL}$ & II true & \\
\hline
\end{tabular}

In the case of the high temperature of the motor about $160{ }^{\circ} \mathrm{C}$ temperature sensor (PTC thermistors as the limit temperature sensor) is used to stop the motor and it restarts if the temperature dropped to $90{ }^{\circ} \mathrm{C}$. That shown Table5.
Table 5: Temperature Sensor Operation.

\begin{tabular}{|c|c|c|c|c|c|}
\hline & Address & Symbol & $\begin{array}{l}\text { Display } \\
\text { format }\end{array}$ & $\begin{array}{c}\text { Status } \\
\text { value }\end{array}$ & $\begin{array}{r}\text { Modify } \\
\text { value }\end{array}$ \\
\hline 1 & MW120 & & DEC & 0 & \\
\hline 2 & MW122 & & DEC & 4096 & \\
\hline 3 & I 0.0 & Start pub & BOOL & talse & true \\
\hline 4 & I 0.1 & Stop pub & $\mathrm{BOOL}$ & false & \\
\hline 5 & I 0.2 & overload & $\mathrm{BOOL}$ & tolse & \\
\hline 6 & I 0.3 & sensor & $\mathrm{BOOL}$ & II true & \\
\hline 7 & Q 4.0 & K1 main contactor & $\mathrm{BOOL}$ & taise & \\
\hline 8 & Q 4.1 & K2 star contactor & $\mathrm{BOOL}$ & false & \\
\hline 9 & Q 4.2 & K3 delta contactor & BOOL & false & \\
\hline 10 & Q 4.3 & marcar & $\mathrm{BOOL}$ & II true & \\
\hline
\end{tabular}

Used Thermal overload relays with three phase motor to Protection of the motor. It is designed to cut off the power for the motor in the event of the pull the electric current of higher than desired and thus guarantee the motors doesn't to damage is shown in table 6.

Table 6: Thermal Overload Relays Operation.

\begin{tabular}{|r|l|l|l|c|c|}
\cline { 2 - 4 } \multicolumn{1}{l|}{} & Address & Symbol & $\begin{array}{l}\text { Display } \\
\text { format }\end{array}$ & $\begin{array}{r}\text { Status } \\
\text { value }\end{array}$ & $\begin{array}{r}\text { Modify } \\
\text { value }\end{array}$ \\
\hline 1 & MW120 & & DEC & 0 & \\
\hline 2 & MW122 & & DEC & 4096 & \\
\cline { 2 - 4 } 3 & I 0.0 & Start pub & BOOL & false & true \\
\hline 4 & I 0.1 & Stop pub & BOOL & toise & \\
\hline 5 & I 0.2 & overload & BOOL & true & \\
\hline 6 & I 0.3 & sensor & BOOL & false & \\
\hline 7 & Q 4.0 & K1 main contactor & BOOL & foise & \\
\hline 8 & Q 4.1 & K2 star contactor & BOOL & folse & \\
\hline 9 & Q 4.2 & K3 delta contactor & BOOL & false & \\
\hline 10 & Q 4.3 & marcar & BOOL & true & \\
\hline
\end{tabular}

All components of the circuit will be stopped if stop push button is press the shown in table 7 .

Table 7: Stop Operation of the Circuit

\begin{tabular}{|c|c|c|c|c|c|}
\hline & Address & Symbol & $\begin{array}{l}\text { Display } \\
\text { format }\end{array}$ & $\begin{array}{c}\text { Status } \\
\text { value }\end{array}$ & $\begin{array}{r}\text { Modify } \\
\text { value }\end{array}$ \\
\hline 1 & MW120 & & DEC & 0 & \\
\hline 2 & MW122 & & DEC & 4096 & \\
\hline 3 & I 0.0 & Start pub & $\mathrm{BOOL}$ & false & true \\
\hline 4 & I 0.1 & Stop pub & BOOL & II true & \\
\hline 5 & I 0.2 & overload & $\mathrm{BOOL}$ & folse & \\
\hline 6 & I 0.3 & sensor & $\mathrm{BOOL}$ & taise & \\
\hline 7 & Q 4.0 & $\mathrm{~K} 1$ main contactor & BOOL & taiso & \\
\hline 8 & Q 4.1 & K2 star contactor & BOOL & tolse & \\
\hline 9 & Q 4.2 & K3 delta contactor & BOOL & false & \\
\hline 10 & Q 4.3 & marcar & BOOL & taise & \\
\hline
\end{tabular}

\subsection{Conclusion and Recommendation}

- In this paper, a PLC simulation program is designed to control the operation of a high power three phase motor used in industry.

- The paper primarily deals with the conversion from start to delta depending on the operation condition of the system where an on delay timer is utilized.

- A Sematic S7-300 simulation PLC is used in the project. The PLC ladder diagram is designed to control the motor and the surrounding temperature. 
- The simulation results prove the efficiency of the design simulation program for controlling and monitoring the ambient temperature and overload.

\section{Recommendation}

To improve the performance of the proposed system the following suggestions could be considered in the future:

Addition of the phase failure and sequence relay to prevent the accidental occurrence of high voltage.

\section{Other Recommendations}

Connected with SCADA system or DCSs.

\section{References}

[1] www.energyefficiencyasia.org, access date: 18/12/2015. Access time 6:00 pm.

[2] http://en.wikipedia.org/wiki/Three-phase_electric_power, access date: 14/12/2015. Access time 1:37 pm.

[3] Magnus Kjellberg and Sören Kling, "Soft starter handbook", ABB Automation Technology Products AB, 2003.

[4] http://ar.scribd.com, access date: 22/12/2015. Access time 9:14 am.

[5] W. Bolton, "Programmable logic controllers", fifth edition, Linacre House, Jordan Hill, Oxford OX2 8DP UK, 2009.

[6] Thomas A. Hughes, "Programmable Controllers", Third Edition, ISA - The Instrumentation, Systems, and Automation Society, 2001

[7] John R. Hackworth and Frederick D. Hackworth, "Programmable Logic Controllers: Programming Methods and Applications", 2007.

\section{Author Profile}

Mohamed Hassan is an Electrical Engineering in AL ZABAWA company group. Mohamed holds a B.Sc. in control system from Alneelain University faculty of engineering in Sudan. And post Graduates student MSC in Control System Engineering at Alneelain University, College of Graduates Studies, in Sudan.

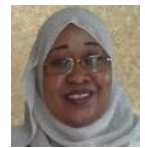

Dalia Mahmoud Assistant Professor and currently Head of Control Systems Department, at Alneelain University, Faculty of engineering In Sudan. Dalia holds a Ph.D. degree and she has more than 10 years' Experience in higher Education filed. 